\title{
Change and Innovation Leadership in an Industrial Digital Environment
}

With the high pace of digital innovation processes the risk of digital disruption increases for industrial companies. However, the progress in industrial digitalization accelerates the decision processes and relieves management from routine work. It gives room for creative management challenges like change and innovation processes. Team-oriented methods like Design Thinking are becoming a crucial part of the innovation culture. Industrial leadership must find current ways that are linked to creativity and to a coordinated human interaction. The article ties together the relevant literature and innovative ideas of digital tools, agile methodology and consequences for a flexible organizational structure.

Keywords: industrial innovation, methodology, tools, agile leadership.

Kartu su didejjančiu skaitmeninių inovacijų procesų tempu didèja ir skaitmeninių trikdžių rizika pramonès ¿̇monèms. Pramonès skaitmenizavimo progresas pagreitina sprendimų prièmimo procesus ir išlaisvina vadovus iš rutinos. İ komandos darbą orientuoti metodai, tokie kaip, Design Thinking, tampa svarbia inovacinès kultūros dalimi. Industrinè lyderystè privalo rasti būdus, kurie susietų kūrybiškumą ir koordinuotų žmonių sąveikas. Straipsnyje aptariama aktuali mokslinè literatūra ir novatoriškos idejos apie skaitmenizavimo įrankius, lanksčią metodologiją ir pasekmes lanksčiai organizacijos struktūrai.

Raktiniai žodžiai: industrinè inovacija, metodologija, ịrankiai, lanksti lyderystè.

\section{Introduction}

With the mechanization of production and the introduction of moving assembly lines, mass production of industrial goods was initiated. A new industrial age began. The division of labour and the definition of supervisory functions introduced the management function by Frederick W. Taylor in The Principles of Scientific Management (Taylor, 1911/2010). With the invention of the semiconductor technology in the early 1950s, numerically controlled digital machines step by step replaced mechanically controlled analogue machinery on the shop floor. Computer technology took over or at least assisted repetitive office work in engineering and in administration. The industrial age of digitalization began. For about fifty years, the dramatic progress in microelectronic technology allowed an exponential efficiency growth of the industrial Information and Communication Technology (ICT). With increasing pace, the value adding processes today are converted into the digital industrial

Dietrich H. STEUDE - Doctor of Industrial Engineering, Professor at the Faculty of Business Administration and Logistics, University of Applied Science Erfurt (retired), Consultant at Senior Experten Service, SES. Address: 14052 Berlin, Kastanienallee 21, Germany. Phone: +49 1702297201. E-mail: dhsteude@gmail.com 
world of Industry 4.0. The progress of the industrial digitalization is followed by the author in his empirical research project evaluating the industrial research results presented over the last 12 years at the world's leading industrial exhibition at Hanover, Germany. In an earlier contribution, the author has discussed the impact of industrial digitalization on business management processes in general (Steude, 2015). Industrial leadership is challenged to manage change and innovation processes keeping pace with the acceleration of the industrial digitalization process. The specificity of leadership in future is the subject of this article. The empirical research findings are complemented by the professional experiences of the author over thirty years as a project manager, head of R\&D-department and CEO in industry together with the research work at the Faculty of Business Administration at the University of Applied Sciences, Erfurt.

The industrial digitalization is not only a disruptive technology to the conventional industrial landscape but influences also the social, technical, and economic structure of industrial enterprises. The challenge is to avoid the disruption of an at present successfully working business model. The aim of the study is to define a future-oriented effective agile organizational structure and leadership culture, an agile methodology and the application of digital design and process tools for an improved innovation efficiency and effectiveness.

\section{Innovation process}

For about 30 to 40 years, lean manufacturing has been the key concept to continuously improve the shop floor efficiency by nominating kaizen teams, introducing Six Sigma toolsets etc., to optimize the production process. The lean management process is sustained mainly by personnel directly involved in the value adding routine end to end.

The innovation management is a corresponding change process, following J. A. Shumpeter's definition "Innovation process is a discontinuous economic and or technical process to introduce new combinations of value adding elements" (Schumpeter, 1964). Different functional departments and external partners are involved (cf. Figure 1).

\begin{tabular}{|l|l|}
\hline Organization Level & Innovative Objects \\
\hline $\begin{array}{l}\text { General } \\
\text { Management }\end{array}$ & $\begin{array}{l}\text { Business Model Innovation } \\
\text { Eco-Innovation }\end{array}$ \\
\hline Management & $\begin{array}{l}\text { Product-, Service-, Market- } \\
\text { Innovation }\end{array}$ \\
\hline Expert Level & $\begin{array}{l}\text { Design-, Process-, Technology - } \\
\text { Innovation }\end{array}$ \\
\hline Professional Level & $\begin{array}{l}\text { Incremental Innovation- } \\
\text { Kaizen }\end{array}$ \\
\hline
\end{tabular}

Fig. 1. Innovative objects

Source: the author's own image.

The strategic concept of an enterprise should be permanently reviewed by top management regarding business model, structure, culture and competitive position of the company. This includes with increasing importance the adaptation of corporate governance principles, i.e., market confidence, business integrity and the ecological footprint of a successful invention. Based on a strategic innovation concept, the market and product innovation must be promoted by the functional management. Target is to avoid a destruction of the present position by new challenges of the global market or technological progress. The competitive position should be strengthened by innovation payoffs during the design and technology 
development phase. A successful change and innovation management should be combined with improved profitability. To reduce the start-up costs by using the "learning curve effect", a permanent efficiency improvement process of incremental innovations on the shop floor level is inevitable.

With the exponential progress in computer technology (Moore's Law) (Yoo, 2015) the innovation culture of enterprises gains in importance. Three driving forces are accelerating the managerial task to permanently review the competitive position of the enterprise (cf. Figure 2). The continuous growth of computing power in capacity and speed is the main driver of the invention of new digital products and services, of efficiency increases in production and distribution, and of the market introduction of disrup- tive new business models. Second driver of the acceleration of innovation cycles is the increasing connectivity of network users, smart material and assets e.g. through the Industrial Internet of Things (IIoT). The more people and goods (IP addresses) are connected to the internal and external network the more valuable the network use becomes." The increase of value is proportional to the square of the number of connected users." (Matcalfe's Law) (Yoo, 2015). Both forces are pushing the globalization of competing as well as cooperating companies worldwide. The global competition is not only restricted to business relations but applies also to the field of scientific knowledge generation, the real-time transfer of information, and exchange of views. Globalization is the third driving force of the industrial change and innovation process.

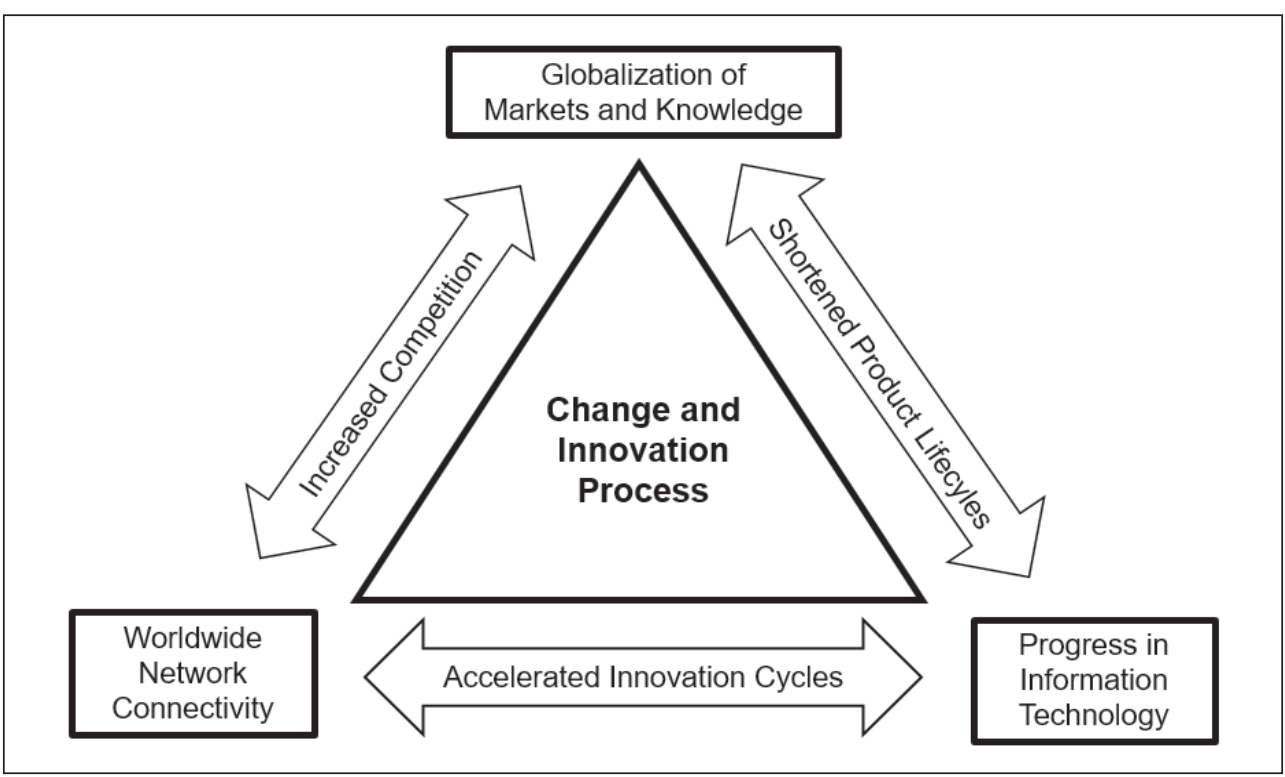

Fig. 2. Change and innovation process - driving forces 
The global competition together with the progress in digitalization of the industrial processes are resulting in a permanent acceleration of innovation cycles. The optimization of the innovation time to market is one of the most important success factors of innovation projects (von Streit, 2016). Organizational measures like innovation leadership, simultaneous engineering, and the use of digital tools are contributing to the reduction of cycle time. New prototyping methods are reducing the time and costs to simulate alternative solutions and to improve testing results. With more and better results in shorter time the number of new innovations can be multiplied (Hyperinnovation) (Schrage, 2017). This phenomenon can be observed looking at native digital companies, like Google, Amazon, Apple or Uber. Industrial companies on their way to transition to digital companies need large financial efforts and time, while enterprises active in the media or commercial market are performing a change of their business mission without high capital expenditures, i.e. using social networks and primarily software products.

\section{Industrial digitalization}

With the foundation of the "Smart Factory Initiative" in 2005, the liaison of production technology and "Industrial Internet" with the introduction of CyberPhysical Systems (CPS) began (Steude, 2015). The first testbed "Industry 4.0" was presented at the Hanover Industrial Fair 2012, demonstrating a flexible manufacturing line controlled by an integrated Enterprise Resource Planning (ERP) and Manufacturing Execution Systems (MES) enterprise software.
The progress of the Industry 4.0 concept in the international industry is limited. One problem is the life and depreciation time of machinery and investment and the incompatibilities of installed software tools like Product Lifecycle Management (PLM), Computer Aided Design (CAD), ERP, MES production software, the missing interface information and other innovation barriers in industry (Nanry et al., 2015).

On the other hand, digitalization and the Industrial Internet of Things (IIoT) will be one of the most important drivers of industrial automation and productivity growth. Compared with other domains like service oriented businesses, the network connected value adding processes in manufacturing companies are lagging behind other branches despite the high automation potential (McKinsey Global Institute, 2015). This may be the reason why the main message at Hanover Fair 2017 regarding the future of Industry 4.0 was not the demonstration of new and futuristic production solutions, but the presentation of new highly integrated production software concepts and draft solutions for international standards to support the technological exchange (Gerundino, 2014) as below:

a. draft Reference Architectural Model Industry 4.0 (RAMI) (Hankel, 2015);

b. open source integration of PLM, ERP, MES, Supply Chain Management (SCM);

c. standardization of interfaces for an increased connectivity of machinery, material, tools, jigs, and products with the IIoT;

d. open source networks (i.e., Local Area Networks (LAN), B2B Internet). 
Standardization enables the integration of software modules of different suppliers. The increase in connectivity supports the collection of valuable data and assists the application of big data analytics. The intelligent evaluation of huge quantities of data is primarily possible with the help of Artificial Intelligence (AI) in a cloud surrounding. About 60 years ago the term AI was introduced for the first time. The development of AI took until today to introduce powerful cognitive computing concepts and applications (IBM's Watson computer) (Kelly III, 2015). To which degree AI will influence the innovation process and the role of management and innovation leadership will be revealed by the future.

\section{Innovation methodology}

The innovation process can be divided into several phases from problem analysis, target definition, ideation to the successful project implementation. These phases are alternately of analytic, creative or of mixed intuitive/logical nature. The analytic tasks of innovation projects can be supported and accelerated by introducing digital tools such as predictive statistics and analytics, big data, rapid prototyping, and simulation. Innovation projects require an agile methodology such as non-linear stage-gate processes, Design Thinking (DT) or lean start-up methodology. The selection of adequate agile project techniques, the evaluation of ideas and project resources are main tasks of the managerial leader in an innovation team as well as on all managerial levels of an agile organization. Compared with the end-to-end standard processes of the industrial valueadded chain, the structure and parameters of innovation processes are more complex (Kaudela-Baum et al., 2014). The organizational requirements can change from project phase to project phase. With this alteration, the cognitive demand for the project leadership is changing too.

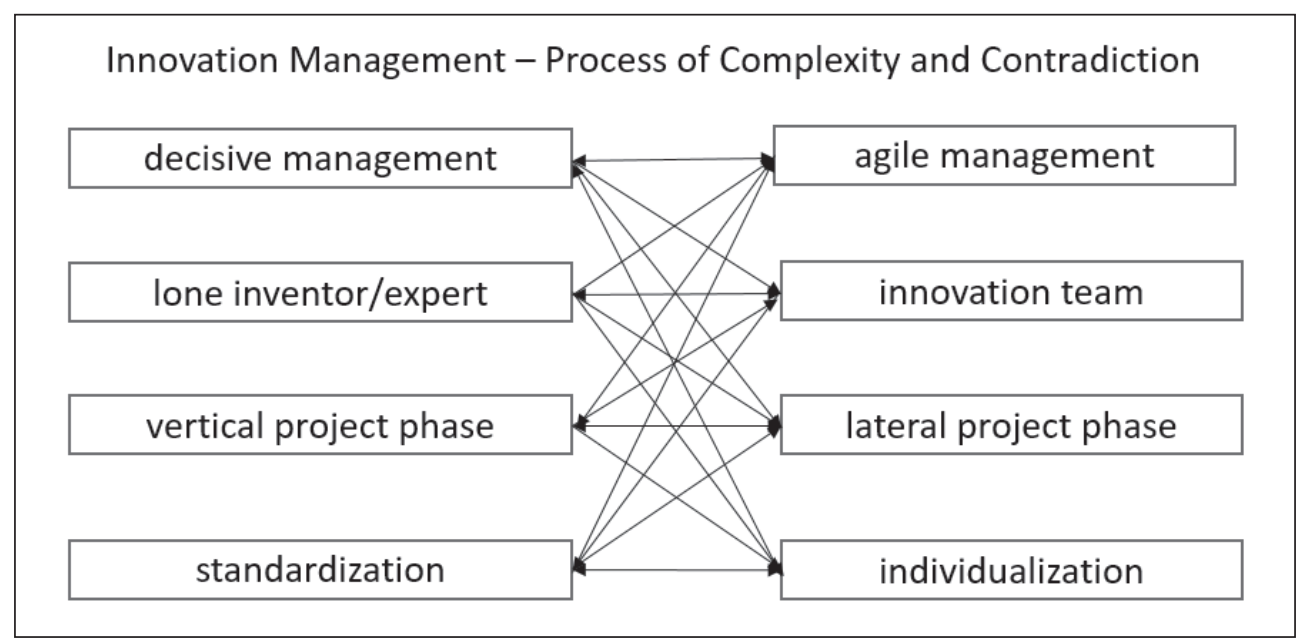

Fig. 3. Innovation process parameters

Source: the author's own image. 
Agile project management (cf. Figure 3) uses an agile methodology of project planning and execution. Not longago software development projects were structured in static linear stage-gate models with a strict quality and cost control, while the agile or SCRUM methodology follows a non-linear sequence of short iterative sessions in small groups. For each session, customer-oriented targets are defined. Changes and failures are accepted. A successfully finished session is followed by a sprint to catch up for possible delays. The creative innovation phases require lateral thinking capabilities, generating multidirectional, and risk minded solutions. The analysis of opportunities of the ideation phase, the exploration of options, and the selection of the best solution require creative innovation teams and an agile project leadership. In other project phases, analytic evaluation of options and decisions are required. In these phases, a stepwise, methodical and logical proceeding, a vertical thinking of the project team and a decisive management style is required (Gloger, 2013).

The size and the composition of the innovation team depends upon the innovation goals. All involved internal and external functions should be represented in cross-functional teams (Hauschildt, 2016). In open innovation projects (Chesbrough, 2003) different partner companies are cooperating in cross-company teams, e.g., as customer/supplier partners or in a $R \& D$ partnership. In this case, project teams must work in a trustful and cooperative style, supported by an agile leadership culture. The increasing cooperation in supply chains and the business globalization leads to an increase of the importance of cross-company innovation projects, which is an additional challenge for the leadership culture of the leading innovation project company. Beside the cross-functional teams, the lone inventor or small groups of experts are necessary in specific implementation phases, especially in the design and technology development phase, where specific know-how is required.

Creative thinking and a standardized innovation management system are contradictive requirements. The standardization of the innovation process is still advisable. It is planned to release the ISO 50501 Innovation Management System in 2018, describing the terminology, the tools, methods, and interactions between innovation partners (ISO/AWI 50501, 2017). The innovation project complexity is permanently increasing. Cross-company and international innovation and $\mathrm{R} \& \mathrm{D}$ partnerships require defined interfaces and definitions. The cooperation should be based on clearly defined rules for the knowledge transfer following the Intellectual Property Rights (IPR) definition of the European Commission (European Commission, 2016). The innovation process follows rules or standards to enable the cooperation in projects of higher complexity. The challenge for the innovation leadership is to define the right balance between process standardization and an agile organization (individualization).

The innovation teams cooperating in the creative phases should be organized in an agile manner, but should also cooperate under defined rules. In the last years, the methodology DT was developed primarily for projects refining the working culture and for projects improving the efficiency of innovation. DT is a problemsolving method. The DT process model today in use has five stages to be worked on by the project team: Empathize - 
serves the collection of customer oriented information to gain an understanding of their needs, Define - the team analyses the collected information and defines the core problem, Ideate - Collecting ideas, which might lead to innovative solutions of the defined problem, Prototype - Fabrication of several prototype versions. In this experimental phase, the prototypes can be tested and improved, Test - the best solutions are going into a detailed testing phase and if necessary changes will be realized and tested again (Schiedgen, 2015). DT is a non-linear process like the SCRUM method. Knowledge, which is gained in a later stage, can be used to change the assumptions of an earlier stage.

DT teams require agile working conditions and must be free from routine work. The working environment should support team cooperation in co-working spaces and areas of individualized retreat equipped with tele-working techniques.
There are companies who have arranged an "Innovation Garage" (Innovation Garage, 2017), where employees are coming together in informal groups from different departments, with different background, and ranks to work on day by day problems or strategic concepts.

\section{Digital process tools}

The digitalization of the innovation process has significantly accelerated the process flow. This effects mainly the analytic or vertical phases of the process, because sequential, logical tasks can be better digitalized. Following the DT non-linear work sequence vertical phases alternate with lateral phases (cf. Figure 4). For several years, IT solutions are available on the market for the analytic project phases. CAD systems have replaced drawingboards in nearly all R\&D departments.

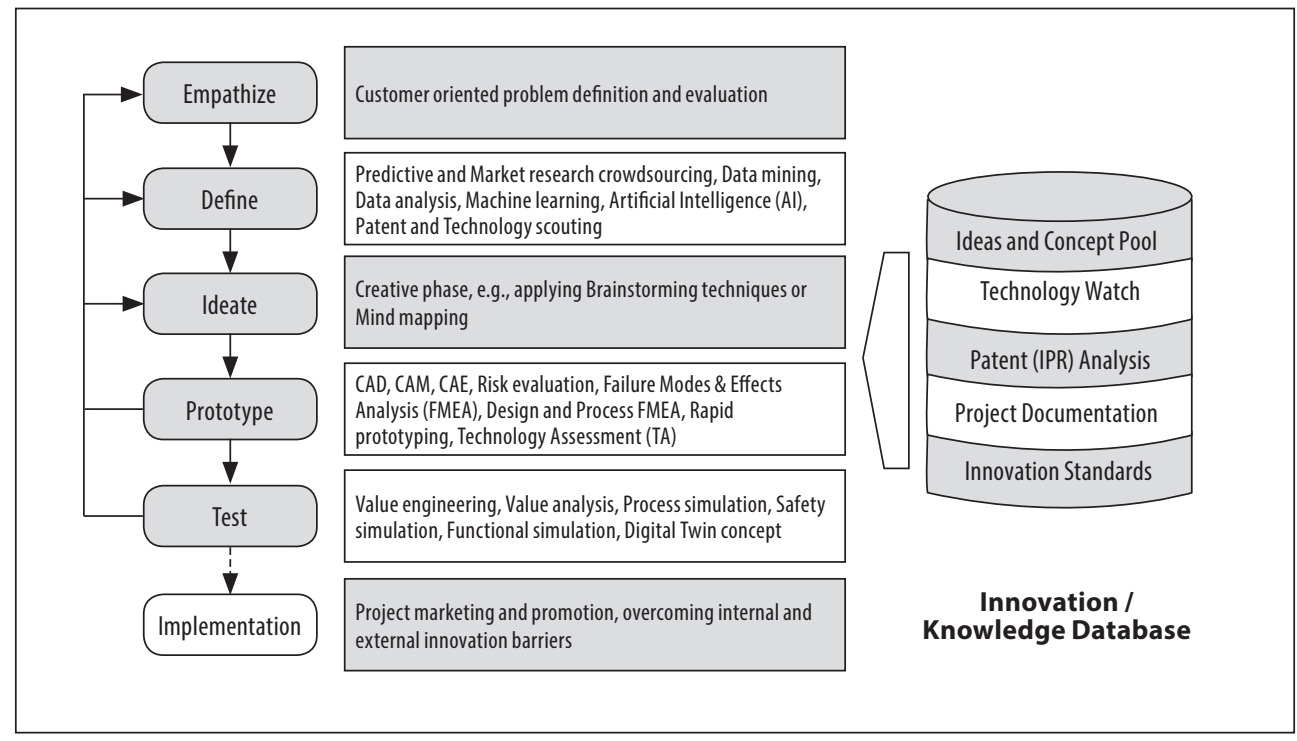

Fig. 4. Innovation process tools

Source: J. Schiedgen (2015), the author's own image. 
Together with CAD computing, CAM and CAE programs like Finite Element Programs (FEM) are in use. R\&D is digitalized in most of the enterprises. Due to the exponential growth of memory capacity and processing speed, the IT efficiency has increased dramatically. With in-memory computing technology, the capacity consuming big data analytics can generate results in real-time.

The latest, state of the art software can be made available through Software as a Service (SaaS) by cloud computing.

AI machine learning method or deep learning enables an automatic analytical model building. An iterative pattern recognition process generates new and more complicated patterns and applications (e.g. automatic language translation). The definition phase requires statistical data from the market, about the status of the competitive situation and possible customer requirements. With crowdsourcing methods special consumer or supplier groups can be activated to generate the required input data and predictive values. With rapid prototyping technology testbeds can be produced to generate early functional tests. Virtual simulations are more and more replacing laboratory tests with increasing efficiency. This can be supported by virtual product models or digital twins, which are used for prototype tests. They can also support the analysis of problems occurring during the lifetime of a product. The digital twin is stored in an innovation and knowledge database. The digital twin is always kept updated to the latest product release. The innovation and knowledge database is a tool, which should support the innovation teams in the exchange of internal and external information and in the coordination of their project activities.

\section{Innovation leadership}

One of the leading management scientists, Peter I. Drucker, described in his book "Innovation and Entrepreneurship" (Drucker, 1985), the growing importance of the management function in a fast changing economic, social and global environment. As main drivers, he identified the impact of globalization, the digital technology combined with an increasing speed of communication. This results in a rising complexity of the industrial decision-making processes. Drucker regards leadership as the important function of management. According to other scientists (Kotter, J. 2013) management and leadership are separate equal ranking functions of managerial positions in an industrial organization. The management function is aligned to optimize industrial processes with best results using the available resources. The focus of management is the routine or standardized process, clearly defined rules, and short- or mediumterm targets. The organizational structure of management is the bureaucracy with a defined reporting and commanding structure.

Leadership is strategically oriented and defines long-term targets based on a common vision. The guidance of personnel is target oriented with flexible rules. The leadership culture is part of an agile organizational culture. With the acceleration of industrial innovation digital tools are replacing standardized routines. The innovation process requires cross-functional, multidisciplinary teams and cooperation in creative agile groups. With the progressing importance of value added supply chains and international cooperation, project teams are collaborating cross-company and often globally. The 
internationally minded innovation leader motivates the team members, solves conflicts, and opens free space for individualism and an atmosphere of failure tolerance. The DT methodology allows failures during the innovation process. "Failures are the prerequisite to invention" (Farson, 2002) if the innovation team learns its "lesson" and avoids doing the same mistake twice. The team must recognize failures as early as possible using efficient simulation tools. The failure tolerant concept requires from management a close process supervision and quality control, to reduce potential risk and damages from mistakes for the enterprise or even their customers.

Digitalization helps automating standard managerial operation processes and standardized innovation process phases. Management information is available real time, predictions are of higher quality. This relieves management from routine work and gives room for creative work. On the other hand, the importance of accelerated innovation processes and their complexity increases and requires a major share of agile leadership.

Innovation management is not only the task of a single organizational department but of many innovation teams. They are cross-functionally organized and cooperating cross-company with other teams in a multi-team innovation network (cf. Figure 5). The agile organizational structure can be called adhocracy. The management and the leadership function in this organization cannot be split into separate managerial positions. With the increasing level of responsibility up to the general management rank, the share of leadership responsibilities of a managerial position increases.

Industrial digitalization has a strong impact on the change and innovation process. The process management must

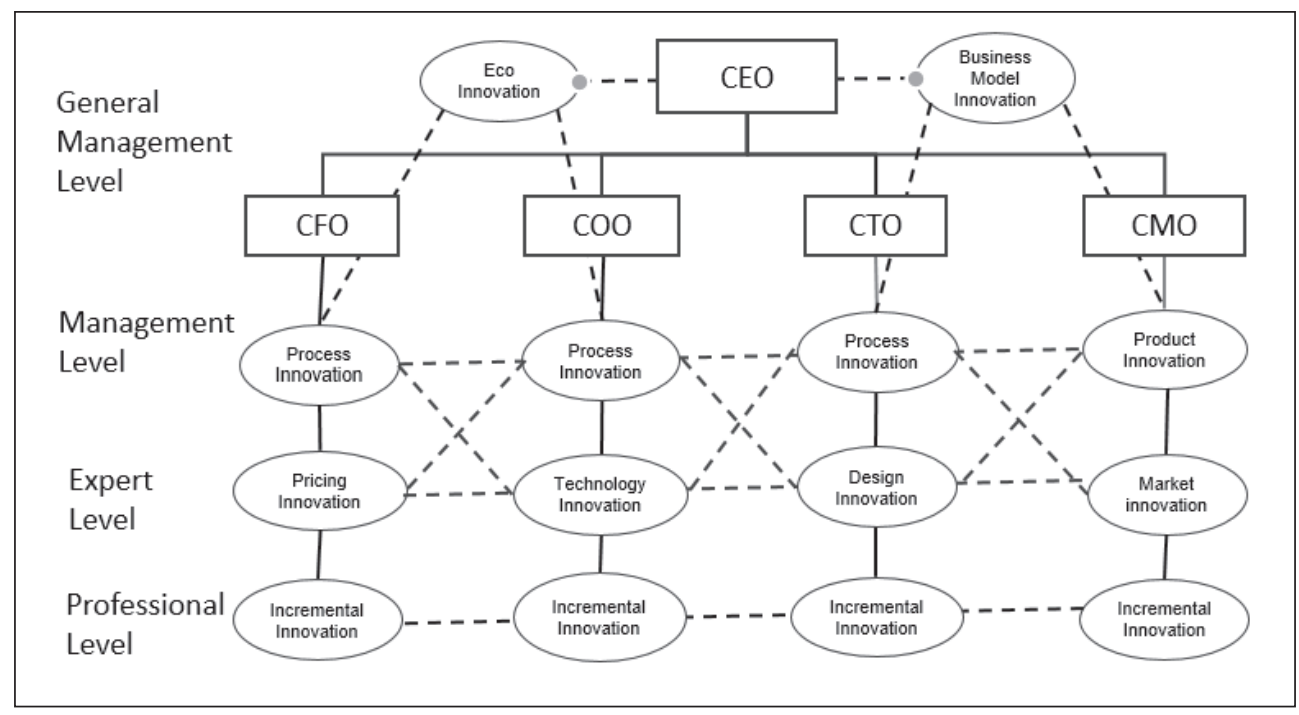

Fig. 5. Multi-team innovation - agile organization

Source: the author's own image. 
select efficient innovation tools and the adequate innovation methodology. Management must lead the decision process within the innovation teams and supports them within the organization. Management must be the promoter of innovation ideas against innovation barriers within a hierarchical organization. The innovation leader motivates the innovation teams and develops an atmosphere of creativity. The innovation leader is long-term oriented. The following two functions of an agile leadership are gaining in importance:

\section{Strategical Enterprise Development}

- Deployment of a strategic enterprise vision;

- Development of a future oriented business mission;

- Definition of strategically important resources and IT tools;

- Definition and organization of cross company and global partnerships;

- Legal preparation of open innovation projects, considering Intellectual Property Rights (IPR) and patent policy;

- Supporting eco-innovation, considering the sustainability of projects and Technology Assessment (TA).

\section{Innovation Team Management}

- Application of customer-oriented Design Thinking techniques;

- Team motivation;

- Conflict resolution;

- Project acceleration, correction and repetition;

- Agile risk management;

- Knowledge management;

- Talent development and/or acquisition;

- Project promotion against internal and external innovation barriers.
Change and innovation management in an agile multi-team organization requires traditional managerial capabilities and creative leadership skills. With an acceleration of the reduction of product cycle times in future the leadership challenge will increase, while management functions will be supported more and more by digital tools.

\section{Conclusions}

Industrial digitalization follows different rules compared to native digital enterprises. The progress of an integrated digital scenario will develop slower than in service, distribution or media-oriented companies. The market entry of disruptive industrial concepts requires higher financial efforts for investments in technology, know-how and start-up. In many cases the required infrastructure or necessary complementary products for a successful market entrance of innovative products is missing. The market introduction of e-mobility for example remains sluggish because the network of loading stations is insufficient. The battery technology is still far behind expectations. E-mobility requires a complete different supply chain network, which must be developed and established with a sufficient production volume behind. Despite these decelerating facts, a successful digital innovation process is of high importance to stay in business and to succeed against the global competition.

The digitalization is supporting a successful innovation process and is accelerating the innovation cycles. Digital tools are available since several years, which have a dramatically improved process performance. They are working intercon- 
nected and open source following the technological innovation process with increasing efficiency and effectiveness. Multi-project networks require standardization of processes and rules, especially for the cooperation in cross-company or international projects. Standard processes and predefined rules however are contradictory to a culture of creativity. The innovation management must define the right balance between process standardization and an agile project organization. The project organization must apply an agile project methodology like Design Thinking. This concept is failure tolerant. That means failures are accepted, even welcome. The failure-tolerant leader must motivate his team in case of failure or success in the same way. It's important to recognize a failure as early as possible. With shortened project phases the evaluation of results must be initiated by the leader using current simulation techniques.

A growing number of change and innovation projects occupy management to an increasing degree from strategic innovation projects on the general management level down to the incremental innovation projects on the shop-floor. The projects are often interconnected. A network organization or agile adhocracy will replace in future more and more the traditional line organization. The agile adhocracy requires a flexible managerial leadership. The focus of the managerial challenge will be more and more the strategic and people oriented leadership in a cross-functional, cross-company and global environment.

One of the most important future digital drivers will be the progress in Artificial Intelligence (AI). AI will not replace primarily conventional labour. But it will change the existing working environment in many functions like $\mathrm{R} \& \mathrm{D}$, marketing, and logistics. It must be seen to which degree creative processes will be supported by AI. This might change the leadership challenge again.

\section{References}

1. Chesbrough, H. W. (2003). Open Innovation. Boston: Harvard Business School Press. Internet access: https://www.iso.org/standard/68221. html [accessed June 15, 2017].

2. Drucker, P. I. (1985/2007). Innovation and Entrepreneurship. - London, New York: Routledge.

3. European Commission, Patents and Standards (2017). Internet access: https://ec.europa.eu/ growth/industry/intellectual-property/patents/ standards_en [accessed May 12, 2017].

4. Farson, R., Keyes, R., (2002). The Failure-Tolerant Leader // Harvard Business Review, August, pp. 64-71.

5. Gerundino, D. (2014). ISO Conference Standardization and Innovation, Geneva.
6. Gloger, B. (2013). Das Scrum-Prinzip, Wirtschaft und Management, Bd. 19, Oktober.

7. Hankel, M. (2015). The Reference Architectural Model Industry 4.0 (RAMI 4.0), ZVEI Frankfurt.

8. Hauschildt, J. et al. (2016). Innovationsmanagement 6., Ed.6, Verlag Franz Vahlen, München pp. 214-225.

9. Innovation Garage (2017). Internet access: http://www.the-innovation-garage.com/ [accessed June 2, 2017].

10. Kaudela-Baum, St. et al. (2014). Innovation Leadership. - Springer Gabler, pp. 1-20.

11. Kelly III, J. E. (2015). Computing, Cognition and the Future of Knowing, IBM Corp. NY 10589. 
12. Kotter, J. P. (2013). Management is (Still) Not Leadership. HBR January 09.

13. McKinsey Global Institute (MGI) (2017). What's Now and Next in Analytics, AI and Automation, March.

14. Nanry, J. et al. (2015). Digitizing the Value Chain // McKinsey Quarterly, March.

15. Schiedgen, J. (2015) What is Design Thinking, HPI, Potsdam. Internet access: http://thisisdesignthinking.net/on- design-thinking/ [accessed May 25, 2017].

16. Schrage, M. (2017). Here Comes Hyperinnovation. Internet access: https://www. strategy-business.com/article $/ 10900$ ?gko $=\mathrm{b} 170 \mathrm{c}$ [accessed June 06, 2017].

17. Schumpeter, J. A. (1964). Business Cycles: A Theoretical, Historical, and Statistical Analysis of the Capitalist Process. - New York: McGraw Hill.
18. Steude, D. H. (2015). Impact of Industrial Digitalization on Business Management Processes // Proceedings of $13^{\text {th }}$ International Scientific Conference, Kaunas, pp. 357-373.

19. Taylor, F. W. (1910/2010). The Principles of Scientific Management. - Cosimo Classics.

20. von Streit, B. M. (2016). Innovationsprojekte schneller zum Erfolg führen - Entscheidungshilfe zur ganzheitlichen Beschleunigung von Entwicklungsprozessen in der chemischen Industrie, Dissertation, Technische Universität Berlin.

21. Yoo, Ch. S. (2015). Moore's Law, Metcalfe's Law, and the Theory of optimal Interoperability, Faculty Scholarship Paper 1651, University of Pennsylvania Law School.

The paper submitted: June 28, 2017

Prepared for publication: December 10, 2017

\section{Dietrich H. STEUDE}

\section{POKYČIŲ IR INOVACIJŲ LYDERYSTĖ INDUSTRINĖJE SKAITMENIZAVIMO APLINKOJE}

\section{S a n t r a u k a}

Industrinès skaitmenizacijos taisyklès, palyginti su vietinèmis skaitmeninèmis įmonèmis, yra kitokios. Integruoto skaitmeninio scenarijaus progresas vystysis lèčiau negu paslaugų, platinimo ar žiniasklaidos įmonių. Pertraukiamųjų pramoninių konceptų ịejimas ị rinką reikalauja didesnių finansinių investicijų i technologijas, žinias (angl. know-how) ir startuolius. Daugeliu atvejų trūksta infrastruktūros ar papildomų produktų sẻkmingam ịejimui ị rinką. Pavyzdžiui, e. mobilumo įdiegimas ị rinką vyksta lètai dèl nepakankamo ịkrovimų stotelių kiekio. Akumuliatoriaus technologija dar toli gražu neatitinka lūkesčių. E. mobilumas reikalauja visiškai kitokio tiekimo grandinès tinklo, kuris turi būti vystomas ir kuriamas su pakankama produkcijos apimtimi. Nepaisant šiu trukdžių, sèkmingas skaitmenizavimo inovacinis procesas yra svarbus versle ir turètų laimèti prieš globalią konkurenciją.

Skaitmenizacija remia sèkmingą inovacijų procesą ir greitina inovacijų ciklus. Pastaruosius kelerius metus skaitmeniniai ịrankiai leido reikšmingai patobulinti procesus. Jie dirba tarpusavyje sujungtais ir atvirais šaltiniais, sekdami technologijų inovacijos procesą, kartu didindami našumą ir efektyvumą. Daugiaprojekčiai tinklai reikalauja procesų standartizavimo ir taisyklių, ypač kai kooperacija vyksta tarp atskirų įmonių arba tarptautinių projektų. Standartiniai procesai ir iš anksto nustatytos taisyklès yra visiška priešprieša kūrybiškumo kultūrai. Inovacijų vadyba privalo rasti pusiausvyrą tarp procesų standartizavimo ir lankstaus projekto organizavimo. Projektų organizavimas turètų taikyti lanksčius metodus, pvz., Design Thinking. Šis metodas tolerantiškas nesèkmėms, tai reiškia, kad klaidos priimtinos, netgi sveikintinos. Nesèkmèms tolerantiškas vadovas turètų gebėti motyvuoti savo komandą tiek sèkmès, tiek nesèkmės atveju. Svarbu pastebèti klaidas kaip įmanoma anksčiau. Sutrumpinus projekto etapus, rezultatų vertinimas, naudojant atitinkamas modeliavimo technikas, turètų būti inicijuojamas vadovo.

Nuolat augantis pokyčių ir inovacinių projektų skaičius vis dažniau nulemia valdymo sprendimų perejjimą nuo strateginių inovacinių projektų bendro valdymo lygmeniu iki taktinių inovaciniu projektų žemiausiame lygmenyje. Projektai dažnai tarpusavyje yra sujungti. Tinklinè organizacija arba lanksti laikina darbo grupé ateityje pakeis tradicinę organizaciją. Lanksti adhokratija reikalauja ir lanksčios vadybinès lyderystès. Valdymo uždavinys bus 
vis labiau orientuotas ị strateginę ir ì žmones nukreiptą lyderystę tarpfunkcinèje, skirtingų i̇monių ir globalinèje aplinkoje.

Vienas iš svarbiausių ateities variklių bus Dirbtinio intelekto (DI) progresas. DI nepakeis tradi- cinių darbo rankų, bet pakeis darbo aplinką, daugelyje funkcijų, pvz., MTEP, rinkodarą ir logistiką. Reikia suprasti, kokiu laipsniu kūrybiniai procesai bus palaikomi DI. Tai gali pakeisti lyderystès iššūki dar kartą. 